\title{
TINJAUAN PUSTAKA SISTEMATIK: PENGARUH KECEMASAN MATEMATIKA TERHADAP KEMAMPUAN PEMECAHAN MASALAH SISWA
}

\author{
Makis Setiawan ${ }^{1}$, Emi Pujiastuti ${ }^{1}$, Bambang Eko Susilo ${ }^{1}$ \\ ${ }^{1}$ Universitas Negeri Semarang \\ *Corresponding email: makis.setiawan8@gmail.com
}

Naskah diterima: 21 Juli 2021| Disetujui: 18 Agustus2021 | Diterbitkan: 20 Agustus 2021

\begin{abstract}
Mathematics anxiety will cause students to become depressed during mathematics learning. This results in students not being able to receive and understand the lesson well. The next thing that happens is that students' solving abilities cannot develop and eventually their learning outcomes become less complete. The purpose of this study was to analyze the effect of mathematics anxiety on students' problem solving abilities. This study uses the SLR (Systematic Literature Review) method. The result of this research is the effect of math anxiety on problem solving ability is negative. Based on the studies reviewed, it can be concluded that the high level of students' mathematics anxiety means that the problem solving ability produced is low, and vice versa. Problem solving ability is strongly influenced by students' mathematical anxiety. Then the math anxiety arises, one of the cause sis that students are less able to understand the concept of the material presented. So as a teacher or teacher, the first thing to fix is to instill in students not to be afraid of mathematics, because mathematics is not as difficult as imagined.
\end{abstract}

Keywords: Literature Review, Mathematics anxiety, Problem solving ability

\begin{abstract}
Abstrak: Terdapat faktor-faktor yang berpengaruh terhadap kemampuan pemecahan masalah siswa yang masih rendah, salah satunya adalah peserta didik tidak menyukai pelajaran matematika tersebut. Kecemasan matematika akan mengakibatkan siswa menjadi tertekan selama pembelajaran matematika berlangsung. Hal tersebut mengakibatkan siswa tidak mampu menerima dan memahami pelajaran dengan baik. Hal yang selanjutnya terjadi adalah kemampuan pemecahan siswa tidak dapat berkembang dan akhirnya hasil belajar menjadi kurang tuntas. Tujuan dari penelitian ini adalah menganalisis pengaruh kecemasan matematika terhadap kemampuan pemecahan masalah perserta didik. Penelitian ini menggunakan metode SLR (Systematic Literature Review). Hasil dari penelitian ini adalah pengaruh dari kecemasan matematika terhadap kemampuan pemecahan masalah bersifat negatif. Berdasarkan penelitian-penelitian yang direview dapat disimpulkan bahwa tingkat kecemasan matematika siswa tinggi, maka kemampuan pemecahan masalah yang dihasilkan menjadi rendah, begitu juga sebaliknya. Kemampuan pemecahan masalah sangat dipengaruhi oleh kecemasan matematika peserta didik. Penyebabnya adalah peserta didik kurang mampu memahami konsep materi yang disampaikan. Jadi sebagai seorang pengajar atau guru, hal yang pertama diperbaiki adalah menanamkan pada diri peserta didik untuk tidak takut kepada pelajaran matematika, karena pelajaran matematika tidak sesulit apa yang dibayangkan.
\end{abstract}

Kata kunci: literature review, kecemasan matematika, kemampuan pemecahan masalah 


\section{PENDAHULUAN}

Pemecahan masalah dalam matematika merupakan keterampilan yang harus dimiliki, karena salah satu indikator keberhasilan dalam pembelajaran matematika adalah kemampuan memecahkan masalah. Anggapan tersebut membuat peserta didik menjadi tidak semangat belajar. Salah satu kemampuan matematis peserta didik yang penting adalah pemecahan masalah. Kegiatan matematika yang dianggap penting oleh para guru dan peserta didik salah satunya adalah kemampuan pemecahan masalah (Rahmadi, 2015). Pemecahan masalah merupakan suatu hal yang penting karena peserta didik dapat menggunakan pengetahuan dan keterampilan yang didapat dari proses pembelajaran untuk diterapkan pada kehidupan sehari-hari. Kemampuan pemecahan masalah matematika merupakan usaha dari peserta didik untuk menggunakan keterampilan dan pengetahuan yang dimilikinya untuk mendapatkan solusi dari masalah matematika (Davita \& Pujiastuti, 2020). Jadi kemampuan pemecahan masalah tersebut harus dilatih dengan cara melakukan aktivitas yang tercakup dalam kegiatan pemecahan masalah.

Pemecahan masalah adalah keterampilan yang kompleks. Hal tersebut dipertegas oleh Swanson, H. Lee yang mengungkapkan bahwa memecahkan masalah matematika memerlukan proses yang kompleks di luar keterampilan komputasi, seperti membaca, menggunakan informasi linguistik dan mengidentifikasi informasi yang relevan (Lee Swanson et al., 2021) Meskipun kompleks, akan tetapi kemampuan pemecahan masalah sangat penting karena salah satu indikator keberhasilan pemebelajaran adalah peserta didik dapat memecahkan masalah. Menurut Branca pemecahan masalah mencakup tiga hal, yaitu pemecahan masalah dipandang sebagai tujuan, proses, dan keterampilan dasar (Angkotasan, 2013).

Definisi lain tentang kemampuan pemecahan masalah yaitu sebagai keterampilan pribadi menganalisis, menjelaskan, menalar, memprediksi, mengevaluasi, dan merenungkan masalah (Anderson, 2009). Pendapat berbeda mengenai pemecahan masalah adalah proses kompleks yang membantu dalam kehidupan sehari-hari dan juga sanagt penting untuk proses pembelajaran yang berkaitan dengan Rekayasa Teknologi Sains dan Matematika (STEM) (Docktor et al., 2016). Kemudian pengertian yang lain mengenai pemecahan masalah adalah situasi baru dan asing, sehingga pemecahan masalah adalah aktivitas mental tingkat tinggi dalam proses individu mencari jawaban yang menerapkan pengetahuan dan teknik yang ada ke alat dan aplikasi untuk memenuhi persyaratan situasi baru (Chao et al., 2017).

Kemampuan memecahkan masalah yang dianggap penting belum mampu dimiliki oleh kebanyakan peserta didik di Indonesia. Menurut survei dari Trend In Mathematics and Science Study (TIMSS) dan Programme for International Student Assesment (PISA), yang dilakukan oleh IEA 
(International Organization for Evaluation of Education Achievement) dari 50 negara yang disurvei kemampuan peserta didik Indonesia dalam memecahkan masalah menempati posisi ke-45. Hal tersebut berarti kemampuan peserta didik di Indonesia dalam memecahkan masalah masih sangat rendah.

Terdapat faktor-faktor yang berpengaruh terhadap kemampuan pemecahan masalah siswa yang masih rendah, salah satunya adalah peserta didik tidak menyukai pelajaran matematika tersebut. Anggapan bahwa pelajaran matematika adalah pelajaran yang sangat sulit dan menakutan masih dirasakan oleh peserta didik masih. Rasa takut terhadap pelajaran matematika akan menimbulkan kecemasan bagi peserta didik. Sehingga timbul kecemasan bagi peserta didik. Kecemasan tersebut dinamakan kecemasan matematika (Math Anxiety).

Kecemasan adalah suatu keadaan yang dirasakan oleh seseorang tidak menyenangkan, disertai dengan sensasi fisik, mengingatkan orang akan bahaya yang akan segera terjadi (Lestari et al., 2020). Pendapat lainnya mengemukakan bahwa kecemasan adalah bentuk emosional individu dari perasaan terancam oleh sesuatu, dan biasanya dengan objek ancaman yang kurang jelas (Ulfiani et al., 2015). Sementara itu pengertian yang lebih spesifik mengenai kecemasan matematika menurut Richardson \& Suinn adalah perasaan gelisah dan tegang yang mengganggu seseorang ketika dihadapkan suatu permasalahan matematika baik dalam akademik maupun kehidupan nyata (Woodard, 2004). Jadi kecemasan matematika tidak hanya dialami dalam akademik saja, namun berpengaruh juga di kehidupan nyata. Ada pengertian lainnya yang mengatakan bahwa kecemasan matematika adalah jenis ketakutan yang akan menghasilkan reaksi negatif ketika melakukan kegiatan matematika dan karena itu kinerja matematika dapat terganggu (Whyte \& Anthony, 2012). Jadi, kecemasan matematika (math anxiety) bisa disebut sebagai ketakutan, menimbulkan kecemasan ketika siswa belajar atau berhubungan dengan pelajaran matematika (Septiarini et al., 2020).

Kecemasan matematika akan mengakibatkan peserta didik menjadi tertekan selama pembelajaran matematika berlanghsung. Hal tersebut mengakibatkan peserta didik tidak mampu menerima dan memahami pelajaran dengan baik. Hal yang selanjutnya terjadi adalah kemampuan pemecahan peserta didik tidak dapat berkembang dan akhirnya hasil belajar menjadi kurang tuntas. Berdasarkan latar belakang tersebut, tujuan dari penelitian ini adalah untuk menganalisis bagaimana pengaruh kecemasan matematika terhadap kemampuan pemecahan masalah perserta didik.

\section{METODE}

Penelitian ini menggunakan metode Systematic Literature Review (SLR). Systematic Literature Review (SLR) dalam bahasa Indonesia dikenal sebagai metode tinjauan pustaka sistematis, yaitu 
metode telaah dokumen yang bertujuan untuk mengidentifikasi, mengevaluasi, dan menjelaskan semua temuan pada suatu topik penelitian, serta untuk menjawab pertanyaan penelitian yang telah ditentukan sebelumnya. Pengertian dari Systematic Literature Review (SLR) adalah suatu metodologi penelitian yang didilakukan dengan cara mengumpulkan dan menganalisis penelitian-penelitian yang terdahulu dengan fokus topik yang dipilih. Peneliti dalam metode ini mengkaji, mengidentifikasi, mengevaluasi, menganalisis, dan melakukan semua penelitian yang ada. Dengan cara ini, peneliti secara sistematis meninjau dan mengidentifikasi jurnal yang mengikuti langkah-langkah yang ditetapkan dalam setiap proses. Tujuan penelitian dengan metode Systematic Literature Review (SLR) adalah untuk mengkaji, mengidentifikasi, mengevaluasi, menganalisis, serta menanfsirkan semua penelitian-penelitian yang telah dipilih dengan fokus yang tertuju pada pertanyaan penelitian.

Berdasarkan pengertian metode penelitian di atas maka peneliti mencari artikel jurnal dengan menggunkan kata kunci pengaruh kemasan matematika terhadap pemecahan masalah peserta didik. Pencarian dokumen dilaksanakan melalui database google scholar. Awal pencarian peneliti menemukan ratusan artikel yang secara umum mendekati apa yang menjadi tujuan penelitian. Akan tetapi secara khusus atau spesifik tidak masuk ke dalam kategori pemilihan artikel jurnal yang akan direview. Batasan-batasan dalam pencarian artikel jurnal sangat diperlukan, karena untuk memfokuskan hasil penelitian, sehingga tujuan dari penelitian ini akan membahas secara lengkap dan detail.

Setelah pencarian selesai, peneliti mengevaluasi hasil pencarian dokumen. Artikel ini dipilih berdasarkan kriteria tertentu untuk mendapatkan artikel yang menjadi sumber penelitian. Beberapa kriteria literatur adalah, (1) literatur khususnya aspek kecemasan dan pemecahan masalah, (2) literatur artikel jurnal yang diterbitkan dari tahun 2015 hingga 2021, (3) akses ke literatur online yang diterbitkan sebagai artikel jurnal yang dapat diterbitkan atau sebagai hasil dari suatu proses. Artikel yang dipilih berdasarkan kriteria ini akan membantu memberikan informasi dan bukti tentang dampak kecemasan matematika terhadap kemampuan pemecahan masalah siswa.

\section{HASIL DAN PEMBAHASAN}

Hasil data penelitian yang termasuk dalam tinjauan pustaka ini adalah analisis dan ringkasan artikel literatur yang berkaitan dengan kecemasan matematika dan keterampilan pemecahan masalah. Terdapat 22 artikel jurnal yang masuk dalam klasifikasi peneliti. 22 artikel dibagi menjadi dua tabel. Secara khusus, berikut tabel hasil penelitian tentang efek kecemasan matematika dan hasil penelitian pada kemampuan memecahan masalah. 
Tabel 1. Sumber Referensi Artikel

\begin{tabular}{|c|c|c|}
\hline No & Fokus & Sumber \\
\hline 1 & $\begin{array}{l}\text { Pengaruh Kecemasan Matematika } \\
\text { terhadap Berbagai Kemampuan } \\
\text { Kognitif }\end{array}$ & $\begin{array}{l}\text { Putri Diana, Indiana Marethi \& Aan Subhan Pamungkas (2020); } \\
\text { Faiq Zulfikas Hadi, dkk (2020); Elvita Novia Dinawati \& Tatag } \\
\text { Yuli Eko Siswono (2020); Evy Novia Nanda Artama, dkk (2020); } \\
\text { Nanda Mellenia Amin Putri dan Ika Kurniasari (2020); Annisa } \\
\text { Juliyanti dan Heni Pujiastuti (2020); Zuraidaha, Tri Hariyati Nur } \\
\text { Indah Sarib, \& Suci Yuniartic (2020); Muhammad Ikhsan } \\
\text { (2019); Rahmat Wijaya, Fahinu, \& Ruslan (2018); Lola Anggun } \\
\text { Nopela, dkk (2020); Wagetama I Disai, Dkk (2017) }\end{array}$ \\
\hline 2 & $\begin{array}{l}\text { Pengaruh Kecemasan Matematika } \\
\text { terhadap Kemampuan Pemecahan } \\
\text { Masalah }\end{array}$ & $\begin{array}{l}\text { Fajar Riski, Indiana Marethi, dan Isna Rafianti (2019); M. } \\
\text { Aunurrofiq dan Iwan Junaedi (2017); Lailatul Lutfiyah, Ettie } \\
\text { Rukmigarsari, dan Abdul Halim Fathani (2019); Hesti Lestari, } \\
\text { Rozi Fitriza, dan Halen A (2020); Ika Septiarini, Nila } \\
\text { Kesumawati, dan Jumroh (2020); Yulia Alawiatul Zahro, dan } \\
\text { Dian Purwaningsih (2018); Ana Setiani (2016); Olivia Khufyatul } \\
\text { Adhimah dan Rooselyna Ekawati (2020); Muhammad Irfan } \\
\text { (2017); Fahriza Noor (2017); Hanuri Sakarti (2018) }\end{array}$ \\
\hline
\end{tabular}

\section{Kecemasan Matematika}

Pendapat pertama mengenai pengertian kecemasan matematika adalah perasaan yang sering muncul dan bersifat tidak nyaman ketika dihadapkan pada permasalahan matematika, di mana perasaan tersebut memiliki hubungan dengan kegelisahan dan ketakutan terhadap matematika (Santri, 2017). Kemudian pendapat lain mengenai kecemasan matematika adalah suatu gejala emosi yang mengakibatkan ketidaknyamanan perasaan, takut, khawatir, gelisah, dan perasaan yang tertekan dalam proses belajar matematika (Lestari et al., 2020). Keadaan seperti kecemasan matematika terjadi kepada peserta didik yang tidak hanya berkaitan dengan pembelajaran matematika yang ada di sekolahan saja, akan tetapi juga berkaitan dengan semua permasalahan di kehidupan sehari-hari yang ada hubunganya dengan angka (Setiani, 2018). Peserta didik akan menghindari suatu hal yang menjadikannya cemas dan takut, termasuk pelajaran matematika. Hal tersebut selaras dengan pendapat yang mengatakan bahwa peserta didik yang memiliki kecemasan matematika tinggi akan menghindar dari hal-hal yang berkaitan dengan matematika (Suárez-Pellicioni et al., 2016). Berdasarkan definisi-definisi kecemasan matematika di atas, maka dapat ditarik kesimpulan bahwa pengertian kecemasan matematika adalah suatu perasaan takut, gelisah, dan khawatir pada diri peserta didik terhadap pelajaran matematika. 
Faktor penyebab timbulnya kecemasan matematika pada diri peserta didik dikemukakan oleh Trujillo \& Hadfield sebagai berikut:

a. Faktor kepribadian

Faktor kepribadian meliputi perasaan takut terhadap kemampuan diri, kurangnya percaya diri, dan trauma akan pengalaman di masa lalu yang buruk.

b. Faktor lingkungan sosial

Faktor lingkungan sosial meliputi paksaan orang tua kepada anakanya untuk bisa pandai dalam pelajaran matematika, guru di dalam kelas yang terkesan menakutkan, dan metode mengajar dari guru yang kurang menarik.

c. Faktor intelektual

Faktor intelektual atau faktor psikologis meliputi tingkat kemampuan berpikir peserta didik dan bakat peserta didik (Anita, 2014).

Hal lainnya yang menyebabkan terjadinya kecemasan matematika adalah kurangnya percaya diri pada peserta didik dalam pembelajaran matematika (Stuart, 2000). Maka dari itu kecemasan matematika begitu berpengaruh terhadap berlangsungnya proses belajar bagi peserta didik.

Sementara itu, akibat yang ditimbulkan dari kecemasan matematika pada diri peserta didik adalah sebagai berikut:

a. Dari segi kognitif

Meliputi peserta didik sukar berkonsentrasi dalam pebelajaran dan tidak mampu berpikir secara tenang dalam belajar.

b. Dari segi afektif

Meliputi peserta didik merasa takut dalam menghadapi ujian dan tidak percaya kepada kemampuan diri sendiri.

c. Dari segi motorik

Meliputi wajah peserta didik akan terlihat pucat saat ditunjukkan untuk menjawab pertanyaan matematika dan akan sering keluar keringat tegang dalam mengerjakan soal-soal yang diberikan guru (Nurmila, 2016).

Ada beberapa indikator dalam mengukur tingkat kecemasan matematika peserta didik. Komponen indikator kecemasan matematika meliputi attitudinal, cognitif, dan somatic (Cavanagh \& Sparrow, 2015). 1) attitudinal, yaitu indikator kecemasan matematika yang muncul pada diri peserta didik berupa atau yang berkaitan dengan sikap peserta didik. 2) cognititif, yaitu indikator kecemasan matematika yang muncul pada peserta didik berupa atau berkaitan dengan perubahan kemampuan 
kognitif peserta didik (seperti tiba-tiba lupa materi pelajaran dan susah untuk berpikir jernih). 3) somatic, yaitu indikator kecemasan matematika yang muncul pada peserta didik berupa atau berkaitan dengan perubahan keadaan tubuh peserta didik (misalnya sering berkeringat dingin atau tegang yang ditandai dengan jantung berdebar kencang).

Kecemasan matematika yang terjadi pada peserta didik memiliki beberapa tingkatan. Ada yang berkecemasan matematika rendah, sedang, dan tinggi. Tingkat kecemasan matematika yang terjadi pada setiap peserta didik berbeda-beda. Semuanya tergantung pada berapa banyak faktor penyebab kecemasan matematika itu bisa terjadi. Berikut adalah tabel mengenai domain kecemasan matematika yang sesuai dengan pendapat di atas.

Tabel 2. Domain Kecemasan Matematika

\section{Domian Kecemasan Matematika}

\begin{tabular}{|c|c|c|c|}
\hline $\begin{array}{c}\text { Tingkat Kecemasan } \\
\text { Matematika }\end{array}$ & Attitudinal & Cognitive & Somatic \\
\hline $\begin{array}{l}\text { Kecemasan matematika } \\
\text { tingkat tinggi }\end{array}$ & $\begin{array}{l}\text { Merasa takut untuk } \\
\text { melakuakn sesuatu }\end{array}$ & $\begin{array}{l}\text { Merasa khawatir jika } \\
\text { dirinya dipandang kurang } \\
\text { mampu (bodoh) oleh } \\
\text { orang lain }\end{array}$ & $\begin{array}{l}\text { Peserta didik merasa } \\
\text { kesulitan dalam bernafas }\end{array}$ \\
\hline $\begin{array}{l}\text { Kecemasan matematika } \\
\text { tingkat sedang }\end{array}$ & $\begin{array}{l}\text { Peserta didik tidak mau } \\
\text { melakukan hal yang } \\
\text { pernah dilakukan } \\
\text { sebelumnya }\end{array}$ & $\begin{array}{l}\text { Peserta didik memiliki } \\
\text { pikiran yang kosong pada } \\
\text { saat pembelajaran }\end{array}$ & $\begin{array}{l}\text { Peserta didik merasakan } \\
\text { detak jantung yang } \\
\text { berdebar dibanding } \\
\text { biasanya pada saat proses } \\
\text { pembelajaran } \\
\text { matematika }\end{array}$ \\
\hline $\begin{array}{l}\text { Kecemasan matematika } \\
\text { tingkat rendah }\end{array}$ & $\begin{array}{l}\text { Peserta didik sudah } \\
\text { menduga bahwa dirinya } \\
\text { akan mendapatkan } \\
\text { kesulitan dalam pelajaran } \\
\text { matematika }\end{array}$ & $\begin{array}{l}\text { Peserta didik merasa } \\
\text { bingung selama proses } \\
\text { pembelajaran } \\
\text { matematika }\end{array}$ & $\begin{array}{l}\text { Peserta didik selama } \\
\text { pembelajaran } \\
\text { matematika merasa tidak } \\
\text { nyaman }\end{array}$ \\
\hline
\end{tabular}

Tingkat kecemasan matematika setiap perserta didik berbeda. Akan tetapi pelajaran matematika mungkin secara umum menjadi suatu momok yang menakutkan bagi peserta didik. Pelajaran matematika dipandang sebagai ilmu yang sulit untuk dikuasai. Mindset seperti itulah yang mengawali pemikiran-pemikiran negatif yang akhirnya tumbuh menjadi kenyataan pada diri peserta didik. Ada beberapa hal yang menyebabkan pelajaran matematika sangat ditakuti oleh peserta didik, yaitu: 1) Matematika adalah cabang ilmu sains yang sifatnya spesifik. Mempelajari matematika melibatkan 
banyak kemampuan kognitif. Dalam ilmu matematika dibutuhkan ingatan yang kuat, ketekunan dalam mengerjakan soal dan mengaplikasikan dalam kehidupan sehari-hari. 2) Matematika dianggap oleh banyak orang sebagai pelajaran yang sangat sulit. Sehingga pesepsi seperti itu memengaruhi mindset peserta didik yang akan belajar matematika. 3) Matematika merupakan pelajaran yang monoton. Guru kurang memberikan inovasi dalam model pembelajaran, sehingga guru terkesan menekan peserta didik selama proses pembelajaran matematika. Dengan begitu kemampuan peserta didik kurang bisa dieksplore karena peserta didik cenderung sering menutup diri dan takut kepada pelajaran matematika dan kepada gurunya.

Setelah mengetahui tingkat kecemasan matematika peserta didik serta faktor yang menjadikan pelajaran matematika ditakuti, pengajar atau guru harus memberikan solusi terhadap masalah yang dialami peserta didiknya. Solusi yang diberikan bertujuan untuk mengurangi atau bahkan menghilangkan rasa cemas selama proses pembelajaran matematika. Solusi yang ditawarkan oleh Freedman dalam mengatasi kecemasan matematika adalah 1) hilangkan ucapan diri yang negatif (pesimis); 2) ajukan pertanyaan pada saat proses pembelajaran matematika; 3) menganggap bahwa matematika adalah bahasa asing yang harus selalu dipraktikkan; 4) dalam belajar matematika jangan mengandalkan halafan; 5) sering membaca buku matematika; 6) memiliki metode belajar sendiri; 7) jika mengalami kesulitan maka segeralah meminta bantuan kepada teman ataupun guru untuk mejelaskan; 8) selama proses pembelajaran matematika usahakan tetap santai dan nyaman; 9) katakan bahwa matematika itu "mudah" dan semua orang mampu menguasainya; 10) selalu mengembangkan tanggung jawab jika hasilnya masih gagal dan bahkan sudah berhasil (Septiarini et al., 2020).

\section{Kemampuan Pemecahan Masalah}

Dewi dkk menjelaskan bahwa kemampuan pemecahan masalah sebagai kemampuan dalam menerapkan ilmu atau pengetahuan yang sudah dimiliki pada diri seseorang ke dalam keadaan yang masih baru dan belum dikenal (Dewi et al., 2019). Kemudian pendapat yang lebih spesifik megenai pemecahan masalah matematika yaitu matematika dapat digunakan sebagai alat dalam menyelesaikan masalah sehari-hari (Ahda, 2018). Berdasarkan pendapat tersebut maka kemampuan pemecahan masalah ini merupakan hal yang penting, baik dalam kehidupan di lingkungan sekolah maupun dalam kehidupan sehari-hari. Hal tersebut didukung oleh pendapat yang mengatakan bahwa kemampuan penting bagi peserta didik, karena tidak hanya membantu dalam memahami pelajaran matematika saja akan tetapi juga membantu dalam menyelesaikan masalah dalam kehidupan sehari-hari (Ariani, 2016).

Dasar dari pemecahan masalah adalah peserta didik dituntut untuk berpikir terlebih dahulu. Hal tersebut sependapat dengan Deway yang memaparkan konsep mengenai berpikir menjadi dasar 
dalam menyelesaikan masalah (Slameto, 2013). Konsep-konsep tersebut diantaranya adalah: 1) peserta didik merasa kesulitan akan suatu masalah; 2) masalah tersebut dibatasi dan diperjelas; 3) mencari dan mengklasifikasikan informasi atau data; 4) mencari apa keterkaitan dari data-data tersebut guna untuk membuat hipotesa, kemudian hipotesa tersebut diuji apakah nilai kebenarannya diterima ataupun ditolak; 5) menerapkan konsep pemecahan masalah sehingga akhirnya didapatkan suatu kesimpulan dari permasalahan tersebut. Jadi kesanggupan atau kemampuan peserta didik dalam menyelesaikan suatu permasalahan yang dihadapi dengan mengguakan strategi dan langkah yang berbeda-beda setiap individu dalam kaitannya memecahkan masalah dalam matematika disebut dengan kemampuan pemecahan masalah matematis.

Pentingnya kemampuan pemecahan masalah bagi peserta didik tidak terlepas dari komponen belajar yang membutuhkan kemampuan berpikir, kemampuan pemecahan masalah, sampai kemampuan mencipta suatu hal yang baru. Kriteria seseorang mampu menguasai kemampuan pemecahan masalah disampaikan oleh Samo, yaitu jika seseorang tersebut mampu menyerap informasi pada suatu masalah secara penuh, kemudian dengan informasi yang sudah didapatkan akan menginspirasi rencana apa yang akan dilakukan untuk memecahkan masalah tersebut, tentunya dengan langkah prosedur yang benar sehingga hasil akhirnya diperoleh kesimpulan dari masalah yang dihadapi (Samo, 2017). Kemampuan pemecahan masalah termasuk kemampuan tingkat tinggi. Maka dari itu kemampuan tersebut harus selalu dilatih oleh peserta didik. Hal tersebut sependapat dengan Marlissa \& Widjajanti yang mangatakan bahwa peserta didik yang mempunyai kemampuan pemecahan masalah berarti dia akan selalu terlatih berpikir pada tingkat tinggi, karena peserta didik dituntut untuk dapat memahami materi (konsep), mengaitkan dengan konsep sebelumnya dan kemudian megaplikasikan di dunia nyata dalam kehidupan sehari-hari (Marlissa \& Widjajanti, 2015).

Menyelesaikan suatu masalah merupakan kegiatan dasar yang harus dimiliki setiap individu. Kehidupan ini tidak terlepas dari suatu masalah. Oleh sebab itu, setiap individu harus mampu memiliki keterampilan dalam menyelesaikannya. Pemecahan masalah menurut pendapat lain mencakup sebuah keberhasilan dalam menciptakan sesuatu bagi seseorang (Slameto, 2013). Hal tersebut berarti seseorang memberikan solusi atas permasalahan yang dihadapi. Kemampuan pemecahan masalah memiliki beberapa aspek. Diantara aspek-aspek tersebut adalah aspek memahami, aspek menggunakan cara (strategi) dan langkah-langkah matematis, dan komunikasi. Aspek memahami yaitu mencakup kemampuan dalam mengklasifiksikan informasi dan data yang diperlukan untuk memecahkan suatu masalah dan dari masalah tersebut kemudian dibuat sebuah model matematikanya. Kemudian aspek strategi mencakup kemampuan memilih strategi dan kemuadin menerapkannya dengan langkah prosedur matematis yang benar. Terakhir aspek 
komunikasi meliputi kemampuan dalam menjelaskan strategi, konsep, dan prosedur yang dilakukan dalam kegiatan pemecahan masalah.

Kendala bagi peserta didik dalam aspek kemampuan pemecahan masalah adalah peserta didik sering mengalami hambatan dalam memahami permasalahan sehingga kurang tepat dalam memilih dan menggunakan strategi penyelesaian. Agar tepat dan efektif dalam kegiatan pemecahan masalah, maka disusunlah suatu indikator atau langkah-langkah dalam pemecahan masalah. Menurut Santrock langkah yang harus dilakukan agar proses pemecahan masalah efektif adalah: 1) peserta didik harus menyusun terlebih dahulu masalah yang ditemukan, peserta didik yang mampu mengungkapkan informasi dari suatu masalah yang diberikan berarti dia dikatakan mampu dengan baik memahami permasalahan; 2) peserta didik mengembangkan strategi dalam penyelesaian masalah; 3) peserta didik memberikan evaluasi terhadap solusi yang diberikan; 4) terhadap masalah dan solusi peserta didik selalu mengidentifikasinya kembali (Entyka, 2016).

Kemudian indikator peserta didik dikatakan mampu menyelesaikan masalah adalah dapat dilihat dari startegi yang dibuat untuk menyelesaikan masalah (Hapizah, 2017). Polya menjeskan tentang tahapan dalam pemecahan masalah yaitu: 1) memahami masalah, artinya peserta didik mampu menangkap permasalahan, menemukan apa yang dikatehaui dan apa yang ditanyakan dalam soal; 2) merencanakan penyelesaian, yaitu peserta didik diharapkan mampu membuat strategi yang efektif untuk permasalahan yang sudah didapatkan sebelumnya; 3) menyelesaikan masalah, yaitu peserta didik menggunakan strategi yang telah disusun sebelumnya untuk menyelesaikan masalah, tentunya langkah prosedur dalam menggunakan strategi yang telah disusun harus benar; 4) memeriksa kembali, artinya setelah langkah-langkah sebelumnya dilakukan peserta didik mendapatkan solusi atas permasalah tersebut. Tidak cukup sampai di situ, kemudian peserta didik harus memeriksa ulang apakah solusi yang didapatkan sudah benar. Ketelitian pada tahap ini sangat diperlukan oleh peserta didik (Polya, 2000).

Menurut Wankat dan Orevocz tahapan strategi operasional dalam pemecahan masalah adalah; 1) saya mampu (I can), artinya pada tahap ini terdapat motivasi untuk menumbuhkan rasa percaya diri bagi peserta didik; 2) mendefinisikan (Define), artinya peserta didik dimbing untuk mendata apa saja yang diketahui dan yang ditanyakan; 3) mengeksplorasi (Explore), artinya memberi stimulan kepada peserta didik sehingga mereka antusias dalam bertanya; 4) merencanakan (Plan), artinya memberikan bimbingan kepada peserta didik untuk membuat suatu strategi yang efektif dalam menyelesaikan permasalahan; 5) mengerjakan (Do it), artinya memberikan bimbingan kepada peserta didik dalam menggunakan strategi yang sudah disusun pada tahap sebelumnya untuk mulai menyelesaikan masalah; 6) mengoreksi (Check it), artinya peserta didik dibimbing untuk memeriksa 
kembali hasil yang telah diperoleh, sehingga hasil kesimpulan akhir diharapkan akan bernilai benar (Wena, 2009).

\section{Pengaruh Kecemasan Matematika terhadap Kemampuan Pemecahan Masalah Matematis}

Menurut Richardson dan Suinn menjelaskan bahwa pengertian kecemasan matematika adalah suatau perasaan cemas dan tertekan yang memengaruhi seseorang dalam memanipulasi suatu masalah matematika baik itu dalam kehidupan akademik sekolah maupun dalam kehidupan sehari-hari (Khatoon, T. \& Mahmood, 2010). Kecemasan matematika ini bersifat negatif karena dapat merusak konsentrasi peserta didik. Kemudian dalam pendapat lain menurut Blazer mengatakan bahwa kecemasan matematika (math anxiety) adalah emosi negatif yang terkait dengan pemecahan masalah matematika (Septiarini et al., 2020). Kemampuan pemecahan masalah pada peserta didik dipengaruhi oleh kecemasan matematika artinya dalam menyelesaikan masalah atau soal peserta didik cemas, gugup, dan tergesa-gesa sehingga hasil skor akhirnya kurang memuaskan. Pendapat lain yaitu kecemasan matematika berpengaruh tidak hanya pada saat peserta didik mengerjakan soal saja, akan tetapi juga pada awal pembelajaran peserta didik sudah merasa cemas, gugup, dan ketakutan dengan pelajaran matematika.

Korelasi negatif antara kecemasan matematika dengan kemampuan pemecahan masalah matematika berarti kecemasan dengan tingkatan tinggi dan kemampuan pemecahan masalah dengan tingkatan rendah, sebaliknya kecemasan matematika dengan tingkatan rendah dan kemampuan pemecahan masalah dengan tingkatan tinggi (Aunurrofiq \& Junaedi, 2017). Adapun menurut Ashcraft dan Faust hal ini berarti bahwa kecemasan matematika adalah perasaan paksaan, kecemasan, bahkan kecemasan, bercampur dengan kesalahan yang tidak biasa dalam angka dan memecahkan masalah matematika (Susanti, Devi W. dan Rohmah, 2011). Dari uraian di atas dapat disimpulkan bahwa kecemasan memiliki hubungan dan pengaruh negatif terhadap kemampuan memecahkan masalah matematika.

Pada artikel penelitian di atas didapatkan informasi bahwa kecemasan matematika dapat memengaruhi beberapa kemampuan kognitif peserta didik, diantaranya adalah kecemasan matematika berpengaruh terhadap kemampuan pemahaman konsep, berpikir kritis, berpikir kreatif, prokastinasi, penalaran adaptif, dan hasil belajar peserta didik itu sendiri. Dari data penelitian yang didapat, kecemasan matematika berpengaruh negatif terhadapat kemampuan-kemampuan yang telah disebutkan di atas. Jika peserta didik berada pada level tertinggi dalam kecemasan matematika, maka peserta didik tersebut memiliki kemampuan-kemampuan kognitif yang rendah. Bahkan pengaruh kecemasan matematika terhadap hasl belajar banyak diteliti oleh peneliti sebelumnya. Hasilnya antara lain adalah kecemasan matematika berpengaruh terhadap hasil belajar sebesar 54,8\%; 66,8\%; sampai 
75,4\%. Semua presentase menunjukkan bahwa kecemasan matematika berpengaruh lebih dari 50\%, itu artinya dampak yang dihasilkan sangat besar. Kemudian dikatakan bahwa peserta didik harus mampu mengendalikan kecemasan matematikanya karena sangat berdampak buruk terhadap hasil belajar peserta didik. Peserta didik dengan kecemasan level tinggi menunjukkna bahwa hasil belajar yang diperoleh rendah. Begitu sebaliknya peserta didik dengan kecemasan level rendah akan memperoleh hasil belajar yang lebih tinggi dari pada peserta didik dengan kecemasan tinggi.

Berdasarkan data penelitian yang dikumpulkan, kecemasan matematika memiliki pengaruh 24,56\%; 31,9\%; 42,9\%; 45,6\% hingga 86,3\% terhadap keterampilan pemecahan masalah. Hal ini menunjukkan bahwa kecemasan matematika memiliki pengaruh yang besar terhadap kemampuan pemecahan masalah siswa. Kemudian pengaruh yang dihasilkan oleh kecemasan matematika ini adalah pengaruh yang bersifat negatif. Artinya jika kecemasan matematika peserta didik meningkat maka kemampuan pemecahan masalah peserta didik tersebut menjadi rendah. Begitu juga sebaliknya, dari 11 artikel jurnal yang berkaitan dengan pengaruh kecemasan matematika terhadap kemampuan pemecahan masalah, semuanya menghasilkan kesimpulan bahwa jika tingkat kecemasan matematika tinggi maka kemampuan pemecahan masalahnya akan menjadi rendah. Jadi hubungan antara keduanya adalah hubungan berbalik nilai. Oleh karena itu diperlukan pengendalian terhadap kecemasan matematika. Hal tersebut diperlukan agar peserta didik dalam belajar maupun menghadapi soal-soal matematika bisa merasa lebih tenang dan fokus, sehingga konsentrasi yang dihasilkan akan lebih maksimal.

Dilihat dari tatapan kemampuan pemecahan masalah secara umum dapat dideskripsikan sebagai berikut. Pada tahap pertama pemecahan masalah, yaitu tahap memahami masalah, peserta didik dengan kecemasan matematika tingkat rendah mampu menginterpretasikan masalah atau soal dengan baik dan sempurna. Mereka mampu menuliskan apa saja yang diketahui dalam soal dan yang menjadi pertanyaan. Kemudian, pada peserta didik tingkat kecemasan matematika sedang juga sudah mampu menginterpretasikan soal, walaupun memang kurang sempurna. Ada beberapa hal dari apa yang diketahui tidak ditulis. Pada peserta didik tingkat kecemasan matematika yang tinggi dalam menginterpretasikan soal cenderung tidak sempurna. Mereka juga tidak mampu menuliskan apa saja yang diketahui dan ditanyakan dari soal.

Tahap kedua dari kemampuan pemecahan masalah yaiu menyusun rencana penyelesaian. Peserta didik dengan tingkat kecemasan matematika rendah mampu menyusun rencana penyelesaian dengan baik. Langkah prosedur yang akan dilakukan juga sudah menuju ke hasil yang benar. Peserta didik dengan tingkat kecemasan matematika sedang juga cenderung mampu menyusun rencana penyelesaian dengan baik. Kemudian, pada peserta didik dengan tingkat kecemasan matematika yang 
tinggi masih ambigu dalam menyusun renacana penyelesaian. Rencana yang dibuat cenderung belum mengarah tepat ke penyelesaian soal.

Tahap ketiga dari kemampuan pemecahan masalah yaitu melaksanakan rencana penyelesaian yang telah disusun pada tahap sebelumnya. Peserta didik dengan tingkat kecemasan matematika yang rendah akan mampu melaksanakan rencana yang telah disusun pada tahap seblumnya dengan langkah prosedur yang benar. Mereka mengerjakan soal dengan tenang dan tanpa ada ketakutan yang menyertai. Sehingga hasil yang diperoleh dari soal tersebut kemungkinan besar akan benar. Pada peserta didik tingkat kecemasan sedang cenderung akan mengalami kesulitan walaupun akhirnya mampu mengerjakan soal. Akan tetapi langkah prosedur yang dilakukan cenderung ada beberapa yang terlewatkan atau kurang teliti dalam pekerjaannya. Kemudian pada peserta didik tingkat kecemasan tinggi mereka tidak mampu melaksanakan reancana penyelesaian, karena memang pada tahap sebelumnya mereka tidak mampu menyusun rencana penyelesaian. Hasilnya, pada tahap selanjutnya juga kesulitan dalam mengerjakan soal tersebut.

Tahap keempat dari kemampuan pemecahan masalah yaitu tahap memeriksa kembali. Pada peserta didik dengan tingkat kecemasan matematika rendah mereka mampu melaksanakan tahap kegiatan memeriksa kembali dengan teliti dan baik. Peserta didik dengan tingkat kecemasan sedang cenderung tidak konsisten dalam memeriksa kembali jawaban yang diperolehnya. Mereka tidak teliti dalam memeriksa ulang atau bahkan tidak memeriksa ulang jawaban yang diperolehnya. Kemudian peserta didik dengan tingkat kecemasan tinggi tidak melakukan tahap memeriksa ulang. Mereka sudah jenuh karena pada tahap sebelumnya kesulitan dalam mengerjakan dan memeroleh hasil jawaban dari soal.

Peserta didik dengan tingkat kecemasan matematika yang tinggi cenderung menghindari masalah matematika atau tampak tidak termotivasi ketika menghadapi masalah matematika. Di dalam kelas peserta didik dengan kecemasan tinggi biasanya cenderung gelisah dan takut yang terlihat di raut wajahnya. Penyebab peserta didik tersebut gelisah dan takut adalah dia merasa tidak bisa atau tidak paham dengan materi yang disampaikan guru. Puncaknya adalah jika seorang guru memberikan pertanyaan atau soal di papan tulis dan menunjuk salah satu peserta didik untuk maju mengerjakan, maka peserta didik degan kecemasan tingkat tinggi akan mengalami puncak kegelisahannya. Kemudian peserta didik dengan dengan tingkat kecemasan matematika yang tinggi akan melakukan segala cara untuk mengerjakan tugas yang diberikan guru. Hal tersebut dilakukan agar terhindar dari kemarahan guru. Menyontek pekerjaan temanpun bisa jadi dilakukannya. Tanda-tanda yang lain yang dirasakan adalah jam pelajaran matematika seakan-akan berlangsung sangat lama dibandingkan dengan pelajaran lain. Hal tersebut terjadi karena peserta didik tidak mampu menikmati pelajaran 
matematika dan berharap ingin secepatnya pelajaran tersebut selesai. Padahal dengan ketidakmampuan peserta didik dalam menikmati pelajaran malah akan membuat waktu pelajaran seakan-akan lama dibanding pelajaran lain.

Peserta didik dengan tingkat kecemasan rendah akan cenderung lebih menikmati suasana belajar di dalam kelas. Mereka dapat menikmati pembelajaran karena awalnya mereka sudah mampu memahami materi yang disampaikan guru. Jadi peserta didik dengan tingkat kecemasan matematika rendah cenderung mampu memahami materi yang disampaikan guru. Sebelum melangkah pada kemampuan pemecahan masalah, maka hal yang penting terlebih dahulu adalah peserta didik harus mempunyai kemampuan pemahaman konsep terhadap materi matematika. Dengan memahami materi terlebih dahulu maka hal seperti kecemasan pun dapat dihindari, sehingga kemampuan pemecahan masalah yang dimiliki dapat dikembangkan. Hal yang perlu diperhatikan agar mempunyai kemampuan pemahaman terhadap materi adalah peserta didik mempelajari terlebih dahulu materi yang akan disampaikan guru. Dengan membaca-baca materi maka peserta didik sedikit banyak akan mengetahui materi apa yang akan disampaikan guru. Dari sini, peran guru sangat berpengaruh. Guru seharusnya selalu membimbing peserta didiknya untuk dapat belajar mandiri. Seperti hanya penerapan kurikulum K-13 guru hanya menjadi fasilitator dari peserta didiknya. Itu berarti peserta didik dituntut aktif dalam kegiatan pembelajaran. Keaktifan dan partisipasi peserta didik dapat dimunculkan oleh guru dengan menerapkan model pembelajaran yang menarik dan tentu saja efektif terhadap pembelajaran.

Kemudian, peserta didik dengan tingkat kecemasan matematika sedang berada di posisi tengahtengah antara tingkat atas dan rendah. Peserta pada tingkatan ini kadang merasa cemas dan gelisah kadang juga merasa santai menikmati pelajaran. Semua itu dapat dipengaruhi oleh kemampuannya dalam menguasai materi. Kembali lagi pada pembahasan kemampuan pemahaman materi atau konsep, jika materinya dirasa mudah dan mereka mampu menguasainya maka peserta didik akan cenderung santai selama proses pembelajaran. Kemudian jika materinya sampai ke materi yang sulit, maka peserta didik tersebut akan mengalami kecemasan yang lebih tinggi.

Dari uraian di atas, peneliti menarik garis besar bahwa kemampuan pemecahan masalah sangat dipengaruhi oleh kecemasan matematika peserta didik. Kemudian kecemasan matematika itu muncul salah satu penyebabnya adalah peserta didik kurang mampu memahami konsep materi yang disampaikan. Jadi sebagai seorang pengajar atau guru, hal yang pertama diperbaiki adalah menanamkan pada diri peserta didik untuk tidak takut kepada pelajaran matematika, karena pelajaran matematika tidak sesulit apa yang dibayangkan. Setelah itu guru juga harus membangun kemampuan peserta didik dalam memahami materi. Model pembelajaran dan kearifan guru dapat membantu 
proses tersebut. Sikap guru yang ramah, murah senyum, dan selalu sabar dalam mengajar adalah kriteria yang diharapkan para peserta didik.

\section{KESIMPULAN}

Kecemasan matematika dapat berpengaruh negatif terhadap kemampuan kognitif peserta didik. Bukan hanya kemampuan pemecahan masalah saja, akan tetapi kemampuan yang lain seperti pemahaman konsep, berpikir kritis, berpikir kreatif, dan penalaran adatif juga dipengaruhi oleh tingkat kecemasan matematika peserta didik. Dari penelitian-penelitian yang direview dapat disimpulkan bahwa jika tingkat kecemasan matematika peserta didik tinggi maka kemampuan pemecahan masalah yang dihasilkan menjadi rendah, begitu juga sebaliknya. Peserta didik dengan kecemasan matematika yang rendah akan menghasilkan kemampuan pemecahan masalah yang tinggi. Kemampuan pemecahan masalah sangat dipengaruhi oleh kecemasan matematika peserta didik. Kemudian kecemasan matematika itu muncul salah satu penyebabnya adalah peserta didik kurang mampu memahami konsep materi yang disampaikan. Jadi sebagai seorang pengajar atau guru, hal yang pertama diperbaiki adalah menanamkan pada diri peserta didik untuk tidak takut kepada pelajaran matematika, karena pelajaran matematika tidak sesulit apa yang dibayangkan. Guru juga harus membangun kemampuan peserta didik dalam memahami materi. Model pembelajaran dan kearifan guru dapat membantu proses tersebut. Sikap guru yang ramah, murah senyum, dan selalu sabar dalam mengajar adalah kriteria yang diharapkan para peserta didik.

\section{REFERENSI}

Ahda, H. (2018). Pengaruh Strategi Pemecahan Masalah Polya Terhadap Hasil Belajar Matematika Siswa. Jurnal Penelitian Pendidikan MIPA, 197(1), 197-201.

Anderson, J. (2009). Mathematics Curriculum Development and the Role of Problem Solving. $1-8$.

Angkotasan, N. (2013). Model PBL dan Cooperative Learning Tipe TAI Ditinjau dari Aspek Kemampuan Berpikir Reflektif dan Pemecahan Masalah Matematis. Pythagoras: Jurnal Pendidikan Matematika, 8(1), 92-100. https://doi.org/10.21831/pg.v8i1.8497

Anita, I. W. (2014). Pengaruh Kecemasan Matematika (Mathematics Anxiety) Terhadap Kemampuan Koneksi Matematis Siswa Smp. Infinity Journal, 3(1), 125. https://doi.org/10.22460/infinity.v3i1.43 
Ariani, S. (2016). Kemmapuan Pemecahan Masalah Matematika Menggunakan Strategi AbduktifDeduktif Di SMA.

Aunurrofiq, M., \& Junaedi, I. (2017). Kecemasan Matematik Siswa dalam Menyelesaikan SoalSoal Pemecahan Masalah. UMJER: Unnes Journal of Mathematics Education Research, 6(2), $157-166$.

Cavanagh, R., \& Sparrow, L. (2015). Measuring mathematics anxiety: Paper 2 - Constructing and validating the measure. AARE 2010 Conference Proceedings. https://espace.curtin.edu.au/handle/20.500.11937/22190

Chao, J. Y., Tzeng, P. W., \& Po, H. Y. (2017). The study of problem solving process of e-book PBL course of atayal senior high school students in Taiwan. Eurasia Journal of Mathematics, Science and Technology Education, 13(3), 1001-1012. https://doi.org/10.12973/eurasia.2017.00654a

Davita, P. W. C., \& Pujiastuti, H. (2020). Anallisis Kemampuan Pemecahan Masalah Matematika Ditinjau Dari Gender. Kreano, Jurnal Matematika Kreatif-Inovatif, 11(1), 110-117. https://doi.org/10.15294/kreano.v11i1.23601

Dewi, N. P. R., Ardana, I. M., \& Sariyasa, S. (2019). Efektivitas Model ICARE Berbantuan Geogebra Untuk Meningkatkan Kemampuan Pemecahan Masalah Matematis Siswa. JNPM (Jurnal Nasional Pendidikan Matematika), 3(1), 109. https://doi.org/10.33603/jnpm.v3i1.1762

Docktor, J. L., Dornfeld, J., Frodermann, E., Heller, K., Hsu, L., Jackson, K. A., Mason, A., Ryan, Q. X., \& Yang, J. (2016). Assessing student written problem solutions: A problem-solving rubric with application to introductory physics. Physical Review Physics Education Research, 12(1), 1-18. https://doi.org/10.1103/PhysRevPhysEducRes.12.010130

Entyka. (2016). Analisis kesalahan siswa dalam pemecahan masalah berdasarkan pendapat John W. Santrock pada pokok bahasan bangun ruang sisi lengkung ditinjau dari gaya belajar dan gaya berpikir siswa. Jurnal Elektronik Pembelajaran Matematika, 4(10), 973-981.

Hapizah, H. (2017). Kemampuan mahasiswa menyelesaikan soal problem-solving mata pelajaran matematika tingkat sekolah menengah pertama. Jurnal Pendidikan Dan Pembelajaran (JPP), 23(2), 124-131. http://journal.um.ac.id/index.php/pendidikan-danpembelajaran/article/view/10163/4850 
Khatoon, T. \& Mahmood, S. (2010). Mathematics Anxiety Among Secondary School Students in India and its Relationship to Achievement in Mathematics. European Journal of Social Science, 16(1), 75-86.

Lee Swanson, H., Arizmendi, G. D., \& Li, J. T. (2021). Working memory growth predicts mathematical problem-solving growth among emergent bilingual children. Journal of Experimental Child Psychology, 201, 104988. https://doi.org/10.1016/J.JECP.2020.104988

Lestari, H., Fitriza, R., \& A, H. (2020). Pengaruh Kecemasan Matematika (Mathematics Anxiety) Terhadap Kemampuan Pemecahan Masalah Peserta Didik Kelas VII MTs. Math Educa Journal, 4(1), 103-113.

Marlissa, I., \& Widjajanti, D. B. (2015). Pengaruh Strategi React Ditinjau Dari Gaya Kognitif Terhadap Kemampuan Pemecahan Masalah, Prestasi Belajar Dan Apresiasi Siswa Terhadap Matematika. Jurnal Riset Pendidikan Matematika, 2(2), 186. https://doi.org/10.21831/jrpm.v2i2.7333

Nurmila. (2016). Hubungan Antara Kecemasan Matematika Dan Kesulitan Belajar Dengan Perilaku Belajar Siswa Di SMPN 3 Tanete Riaja Kabupaten Barru.

Polya, G. (2000). How to Solve It: A New Aspect of Mathematical Method. https://books.google.co.id/books?hl=id\&lr=\&id=z_hsbu9kyQQC\&oi=fnd\&pg=PP2\&dq=Poly a,+G.+2000.+How+to+Solve+it:+A+New+Aspect+of+Mathematical+Method.+Princeton+Un iversity+Press.\&ots=oZkLRhrSMa\&sig=Ka1x14uWoMLBmajFPUYgwM2vp4\&redir_esc=y\#v=onepage $\& \mathrm{q} \& \mathrm{f}=$ false

Rahmadi, F. (2015). Pengembangan Perangkat Pembelajaran Berbasis Pemecahan Masalah Berorientasi pada Kemampuan Penalaran dan Komunikasi Matematika. Jurnal Pendidikan Matematika, 10(2), 137-145.

Samo, D. D. (2017). Kemampuan pemecahan masalah matematika mahasiswa tahun pertama dalam memecahkan masalah geometri konteks budaya. Jurnal Riset Pendidikan Matematika, 4(2), 141. https://doi.org/10.21831/jrpm.v4i2.13470

Santri, F. S. (2017). Ada Apa Dengan Kecemasan Matematika? Journal of Medives , 1(1), 59-65. http://e-journal.ikip-veteran.ac.id/index.php/matematika

Septiarini, I., Kesumawati, N., \& Jumroh, J. (2020). Pengaruh Kecemasan Matematika Terhadap Kemampuan Pemecahan Masalah Matematis Siswa Smp Negeri Se-Kecamatan Banyuasin. Journal of Mathematics Science and Education, 3(1), 8-16. https://doi.org/10.31540/jmse.v3i1.951 
Setiani, A. (n.d.). MATEMATIS SISWA MTs DENGAN PENDEKATAN PBL. 4.

Slameto. (2013). Belajar dan Faktor-faktor yang Mempengaruhi. Rineka Cipta.

Stuart, V. (2000). Math Curse or Math Anxiety? Teaching Children Mathematics, 6(5), 330-335. https://doi.org/10.5951/TCM.6.5.0330

Suárez-Pellicioni, M., Núñez-Peña, M. I., \& Colomé, À. (2016). Math anxiety: A review of its cognitive consequences, psychophysiological correlates, and brain bases. Cognitive, Affective and Behavioral Neuroscience, 16(1), 3-22. https://doi.org/10.3758/s13415-015-0370-7

Susanti, Devi W. dan Rohmah, F. A. (2011). Efektivitas musik klasik dalam menurunkan kecemasan matematika. Humanitas, 8, no 2(Agustus), 130-142. http://www.academia.edu/download/40524096/peran-religious-coping-sebagai-moderatordari-job-insecurity-terhadap-stres-kerja-pada-staf-akademik.pdf

Ulfiani, R., Nursalam, N., \& M. Ridwan, T. (2015). Pengaruh kecemasan dan kesulitan belajar matematika terhadap hasil belajar matematika pada siswa kelas x ma negeri 1 watampone kabupaten bone. MaPan: Jurnal Matematika Dan Pembelajaran, 3(1), 86-102. http://journal.uin-alauddin.ac.id/index.php/Mapan/article/view/2752

Wena, M. (2009). Strategi Pembelajaran Inovatif Kontemporer Suatu Tinjauan Operasional. Bumi Aksara.

Whyte, J., \& Anthony, G. (2012). Maths Anxiety: The Fear Factor in the Mathematics Classroom. New Zealand Journal of Teachers' ..., 9(1), 6-15. http://www.teacherswork.ac.nz/journal/volume9_issue1/whyte.pdf

Woodard, T. (2004). The effects of math anxiety on post-secondary developmental students as related to achievement, gender, and age. Inquiry, 9(1), 1-5. 